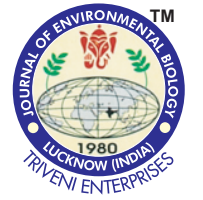

\title{
Differential crop load and hormonal applications for enhancing fruit quality and yield attributes of grapes var. Flame Seedless
}

\section{Authors Info}

S. Singh*, N. K. Arora, M.I.S. Gill and K. S. Gill

Department of Fruit Science, Punjab Agricultural University, Ludhiana - 141 004, India

*Corresponding Author Email : sukhsagarsingh77@gmail.com

Key words

Abscisic acid,

Fruit quality,

Pre-harvest treatment,

Seedless grapes

Publication Info

Paper received : 03.01.2016

Revised received : 09.05.2016

Re-revised received : 23.08 .2016

Accepted : 06.10.2016

\section{Abstract}

Aim : Recently, introduced grape cv. Flame Seedless has uneven berry colour problems under subtropical climatic conditions of northern India.Probably due to high temperature at the time of ripening in subtropical conditions, which inhibit the accumulation of anthocyanins is the major cause of this malady. It is evident that by reducing crop load and application of abscisic acid (ABA) helpful for attainment of uniform and improved quality bunch in grapes. Hence, the present study was conducted to study the combined impact of various levels of crop load and pre-harvest treatments of $A B A$ on fruit quality (uneven colour of berries/bunch, anthocyanin content, yield, berry and bunch weight, total soluble solids (TSS), total sugars and time of ripening) of grapes cv. Flame Seedless.

Methodology : Vines were retained with three levels of crop load thinned at pea stage viz., 50\% (50-65 bunches/vine $), 75 \%(80-90$ bunches/vine) and $100 \%(110-120$ bunches/vine). These treatments were compounded with three concentrations of $\operatorname{ABA}(50,100$ and $150 \mathrm{ppm})$ applied as foliar sprays at veraison stage.

Results : Grape vines with $50 \%$ crop load (50-65 bunches/vine) and 150 ppm ABA had better development of berry colour $(14.60 \%$ uneven colour of berries/bunch), ripened 4 days earlier, higher anthocyanin content (41.78 $\mathrm{mg} 100 \mathrm{~g}^{-1}$ ) and bunch weight (375.33 g) as compared to control vines. However, application of $100 \mathrm{ppm}$ ABA at $50 \%$ crop load (50-65 bunches/vine) had relatively more berry weight $(3.25 \mathrm{~g})$, total sugar content $(16.14 \%)$ and TSS (19.15\%). The highest fruit yield ( $32.60 \mathrm{~kg} / \mathrm{vine})$ was recorded with $100 \%$ crop load (110-120 bunches/vine) and 100 ppmABA.

Interpretation: The results of the present study showed that 100 to $150 \mathrm{ppm}$ application of $\mathrm{ABA}$ at veraison coupled with low crop load 50\% (55-65 bunches/ vine) would be helpful in uniform colouration of bunch with improved fruit quality.

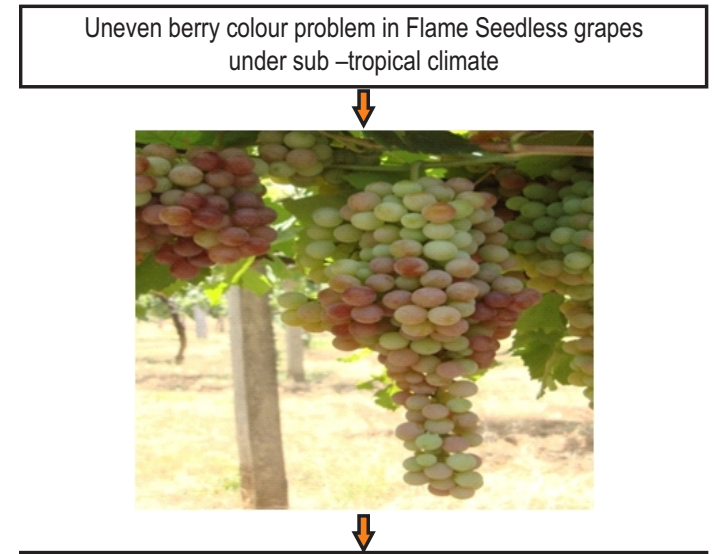

100 to $150 \mathrm{ppm}$ application of abscisic acid (ABA) at veraison coupled with low crop load $50 \%$ (55-65 bunches/ vine) could helpful in uniform colouration of bunch with improved fruit quality

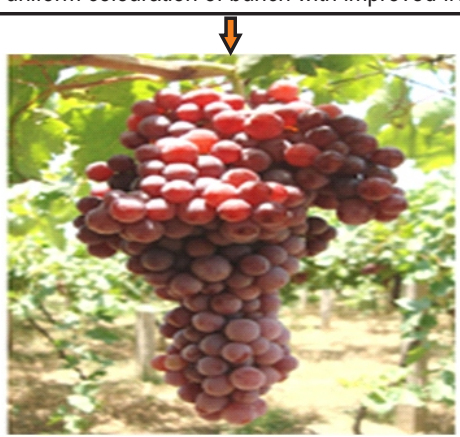




\section{Introduction}

Grape (Vitis vinifera) is an important fruit crop grown in sub-tropical and temperate regions across the world. It is third most widely cultivated fruit after citrus and banana in the world. India occupies ninth rank with $3.31 \%$ share of the worlds production. In India grapes are commercially grown in Maharashtra, Karnataka, Andhra Pradesh and Tamil Nadu. The states of north-western regions consist of Punjab, Haryana, Uttar Pradesh, Rajasthan and Madhya Pradesh also hold the potential for successfully growing short duration, good quality varieties of grapes. At present, in India, it occupies an area of 1.2 lakh ha with an annual production of 26.02 lakh MT (Anonymous, 2014).

The coloured grape variety 'Flame Seedless' has been recently recommended by the Punjab Agricultural University, Ludhiana for commercial cultivation in the Punjab and adjoining states of North India. This variety has an edge over commercial grape variety Perlette as it has crimson red colour, seedless berries, relatively higher yield and better TSS/acid ratio. Its cultivation is helpful in breaking monoculture of Perlette vis-à-vis reducing glut in market. Although, it has many advantages over Perlette, but Flame Seedless grapes failed to achieve the desired level of red color, probably due to high temperature at the time of ripening under subtropical conditions, which inhibit the accumulation of anthocyanins (Spayed et al., 2002). At ripening, bunches with uneven colour (presence of light red/green berries) was observed which reduced its market value and fetch economic losses to the growers.

Previously, various workers had tried to improve quality and colour of Flame Seedless grapes by reducing crop load and application of ethephon (Kaur et al., 2013). However, ethephon releases ethylene, a growth retardant would pose a negative impact on important properties of berries such as firmness and shelf life (Peppi et al., 2006).

As evidenced by recent research reports, in grapes, anthocyanin accumulation begins at veraison stage (onset of ripening). This accumulation appears to be regulated by the plant hormone abscisic acid (Hiratsuka et al., 2001 and Ban et al., 2003) and exogenous applications of ABA increased the anthocyanin content of grape skins (Peppi et al., 2006). Furthermore, there is convincing evidence that $A B A$ can enhance physio-chemical properties of grape berries such as average berry and volume (El-Sayed, 2013), fruit firmness, total anthocyanin and TSS (Amiri et al., 2010), acidity (Peppi et al., 2006) and total sugars (Giribaldi et al., 2011). ABA concentration increases at ripening, therefore, it is believed that $A B A$ plays an important role in regulating the rate of fruit ripening (Setha, 2012). Likewise, a total soluble solid (TSS) is an important attribute for measuring quality of table grapes and it has inverse correlation with number of bunches per vine. The grapes harvested from vine with lesser number of bunches had more total soluble solids (TSS) i.e., more sweeter as compared to grapes harvested from vine having more number of bunches than desired. Similar results have been observed earlier in grapes (Sun et al., 2012 and
Somkuwar et al. 2014), where reduction in clusters per vine lead to increased total soluble solids in grape berries. Hence, in light of the above, the present study was conducted to investigate the effects of crop load (bunches/vine) and ABA on berry colour and fruit quality parameters like TSS and total sugars in grapes cV. Flame Seedless.

\section{Materials and Methods}

The present experiment was conducted on eleven year old vines of Flame Seedless grapes in Fruit Research Farm, Department of Fruit Science, Punjab Agricultural University, Ludhiana, Punjab, India, during 2012-2013 fruiting season. The own-rooted Flame Seedless grapevines having uniform growth, trained on bower's training system, planted at $3 \mathrm{~m} \times 3 \mathrm{~m}$ distance and managed with uniform cultural practices were selected for studies. The vines were retained with three levels of crop load thinned at pea stage viz. $50 \%$ (50-65 bunches/vine), $75 \%$ (80-90 bunches/vine) and $100 \%$ (110-120 bunches/ vine). These treatments were compounded with three concentrations of abscisic acid (ABA-50,100 and 150 ppm) applied as foliar sprays at veraison stage. An additional treatment of $75 \%$ crop load +400 ppm ethephon, earlier recommended for uniform colour development in Flame Seedless grapes in subtropical conditions was also included in the study for comparison. The treatments given are as followes $\mathrm{T}_{1}\left(\mathrm{CL} 100 \%\right.$ - Control); $\mathrm{T}_{2}(\mathrm{CL} 75 \%) ; \mathrm{T}_{3}(\mathrm{CL}$ $50 \%) ; \mathrm{T}_{4}(\mathrm{CL} 100 \%+50$ ppm ABA $) ; \mathrm{T}_{5}(\mathrm{CL} 100 \%+100$ ppm ABA); $\mathrm{T}_{6}(\mathrm{CL} 100 \%+150 \mathrm{ppm} \mathrm{ABA}) ; \mathrm{T}_{7}(\mathrm{CL} 75 \%+50 \mathrm{ppm} \mathrm{ABA}) ;$ $\mathrm{T}_{8}(\mathrm{CL} 75 \%+100 \mathrm{ppm} A B A) ; \mathrm{T}_{9}(\mathrm{CL} 75 \%+150 \mathrm{ppm} \mathrm{ABA}) ; \mathrm{T}_{10}(\mathrm{CL}$ $50 \%+50$ ppmABA); $T_{11}\left(\right.$ CL $50 \%+100$ ppmABA); $T_{12}(C L 50 \%+$ 150 ppm ABA) and $\mathrm{T}_{13}$ (Crop load $75 \%+400$ ppm ethephon).

For preparing an aqueous solution of $\mathrm{ABA}$, commercial grade $A B A$ (S-ABA $10 \%$ a.i.) was used. The required concentration was worked out based on the per cent active ingredient and dissolved in small amount of alcohol, prior to making final volume with water. Tween $20 \circledR$ (Sigma Aldrich Co., USA) @ of $0.1 \%$ was added to obtain better retention and absorption of ABA solution. The prepared solutions were sprayed directly to the clusters of vines at veraison (10\% of the berries of $50 \%$ of the clusters are at colour break) until run-off. Bunches were harvested manually, placed in plastic crates, lined with paper clippings and transported to the viticulture laboratory of the department for physico-chemical analysis. The observations on total soluble solids (TSS) of fruits from each vines was recorded daily during the $1^{\text {st }}$ week of June, when the fruit crossed value of TSS $16 \%$ and more than $75 \%$ of bunches on vines attained uniform colour was considered the time of ripening.

The yield $(\mathrm{kg})$ was recorded by multiplying the number of bunches per vine with average bunch weight. The weight of 100 randomly selected berries was taken with weighing balance and the average berry weight for each treatment was calculated. The weight $(\mathrm{g})$ of ten randomly selected bunches from each vine was recorded at the time of harvesting and mean weight of the bunch 
was calculated. Total sugar content of the fruits was estimated according to the method described in A.O.A.C. (2005). The total sugars were calculated and expressed in percentage. Skin of the berry showing less than $50 \%$ area without colour development was counted as uneven coloured berries. Percentage of uneven coloured berries was calculated by counting total number of uneven coloured berries out of total number of berries per bunch. Total anthocyanin content of berries was determined with extraction solvent ethanolic $\mathrm{HCl}$ and absorbance was noted at $535 \mathrm{~nm}$ wavelength on spectrophotometer (Ranganna, 1986).

Experimental design and analysis : The experiment was laid out as Randomized Block Design (RBD) with three replications in each treatment. In total, thirty nine vines constituted the experimental block. The data were analyzed for variance by using SAS (V 9.3, SAS Institute Inc., USA). The treatment means which were significant at $p \leq 0.05$ were subjected pairwise means comparison by LSD $(p \leq 0.05)$.

\section{Results and Discussion}

The effect of different crop load and ABA application on ripening of Flame Seedless grapes showed that $50 \%$ crop load vines treated with 100 and 150 ppm ABA ripened 4 days earlier as compared to control vines (Fig.1). Berries in both these treatments (100 ppm and $150 \mathrm{ppm} A B A$ ) ripened early and developed more uniform colour, than control. Grapes of $75 \%$ crop load vines treated with two different doses of $A B A(100,150 \mathrm{ppm})$ led to advance ripening by 3-days than control. Similarly, Cantin et al., (2007) observed that treatment with $150 \mu^{l^{-1}}$ of ABA allowed grapes to be harvested 10 days before untreated fruits, and early harvest was possible because the treatments induced more rapid colouring of the grapes. ABA concentration is very low in unripe fruit, but it increases as fruit ripens, therefore, it is believed that ABA plays an important role in regulating the rate of fruit ripening (Setha, 2012).
Application of treatment $\mathrm{T}_{5}$ (crop load $100 \%+100$ ppm $A B A$ ) resulted in higher yield ( $32.60 \mathrm{~kg} / \mathrm{vine})$ followed by $\mathrm{T}_{4}(30.67$ $\mathrm{kg} / \mathrm{vine})$ and $T_{6}(31.48 \mathrm{~kg} / \mathrm{vine})$ as compared to control vines which recorded a yield of $29.74 \mathrm{~kg} / \mathrm{vine}$ (Table 1). Full crop retention (100\%), irrespective of hormonal treatment resulted in higher yield. In these treatments, grapevines was retained with $100 \%$ crop load and treated with different concentrations of ABA $(50,100$ and $150 \mathrm{ppm})$ at veraison stage, which showed that concentration of $A B A$ did not affect the yield to any significant extent at $100 \%$ crop load. However, crop reduction up to $75 \%$ along with foliar application of ABA (100 ppm) resulted in similar yield potential as in full crop load as berry quality in terms of size and weight compensated the reduced crop load in the latter treatment. The treatments in which $50 \%$ crop load +50 ppm ABA was sprayed, recorded $22.12 \mathrm{~kg}$ fruit yield per vine, which was slightly higher than treatment $\mathrm{T}_{3}$ (untreated $50 \%$ crop load grape vines) in which $21.50 \mathrm{~kg} / \mathrm{vine}$ yield was recorded. However, decrease in crop load from 100 to $50 \%$ resulted in reduced yields due to reduction in number of bunches per vine.

Highest berry weight $(3.25 \mathrm{~g})$ was recorded at lowest crop load level (50\%) with $100 \mathrm{ppm}$ ABA application at veraison stage. In case of control (100\% crop load) without any application of $\mathrm{ABA}$, minimum berry weight $(2.10 \mathrm{~g})$ was recorded (Table 1$)$. Results, showed that the grapevines with lower number of bunches had more berry weight because bunch thinning resulted in less bunch count per vine which provided more photosynthates and space on the vines to the left over berries in bunches. These results are in conformity with the findings of El-Sayed (2013) who found that vines of cv. Crimson Seedless sprayed with S-ABA (Pro-Tone) showed an increase in average berry weight and volume. The data (Table 1) on bunch weight showed that abscisic acid $(A B A)$ and reduced crop load had significant effect on bunch weight of Flame Seedless grapes. All the treatments increased the bunch weight as compared to untreated vines (control).

Table 1 : Effect of crop load (bunches/vine) and abscisic acid application on yield, berry and bunch weight of Flame Seedless grapes

\begin{tabular}{|c|c|c|c|c|}
\hline S. No. & Treatment & Yield (kg/vine) & Berry weight (g) & Bunch weight (g) \\
\hline $\mathrm{T}_{1}$ & Crop load (100\%) - Control & $29.74^{\mathrm{bc}}$ & $2.10^{\mathrm{h}}$ & $270.36^{e}$ \\
\hline $\mathrm{T}_{2}$ & Crop load $(75 \%)$ & $24.24^{\dagger}$ & $2.39^{\text {efgh }}$ & $306.55^{\mathrm{bcd}}$ \\
\hline $\mathrm{T}_{2}$ & Cropload (50\%) & $21.50^{h}$ & $2.75^{\mathrm{cd}}$ & $320.75^{\mathrm{bc}}$ \\
\hline $\mathrm{T}_{4}$ & Crop load $(100 \%)+50$ ppm ABA & $30.67^{\mathrm{abc}}$ & $2.29^{\text {ggh }}$ & $280.31^{\text {de }}$ \\
\hline $\mathrm{T}_{5}$ & Crop load $(100 \%)+100$ ppmABA & $32.60^{\mathrm{a}}$ & $2.48^{\text {defg }}$ & $298.68^{\text {cde }}$ \\
\hline $\mathrm{T}_{6}$ & Crop load $(100 \%)+150$ ppm ABA & $31.48^{\mathrm{ab}}$ & $2.24^{\text {gh }}$ & $302.67^{\text {bod }}$ \\
\hline $\mathrm{T}_{7}$ & Crop load $(75 \%)+50$ ppm ABA & $26.35^{\mathrm{e}}$ & $2.62^{\text {cdef }}$ & $314.31^{\mathrm{bc}}$ \\
\hline $\mathrm{T}_{8}$ & Crop load $(75 \%)+100$ ppmABA & $28.79^{\text {cd }}$ & $2.69^{\text {cde }}$ & $330.32^{b}$ \\
\hline $\mathrm{T}_{9}$ & Crop load $(75 \%)+150$ ppmABA & $26.75^{\mathrm{de}}$ & $2.77^{\text {cd }}$ & $317.33^{\mathrm{bc}}$ \\
\hline $\mathrm{T}_{10}$ & Crop load $(50 \%)+50$ ppm ABA & $22.12^{\text {gh }}$ & $2.92^{\mathrm{abc}}$ & $330.55^{b}$ \\
\hline$T_{11}$ & Crop load $(50 \%)+100$ ppm ABA & $23.72^{\text {fg }}$ & $3.25^{\mathrm{a}}$ & $360.00^{\mathrm{a}}$ \\
\hline $\mathrm{T}_{12}$ & Crop load $(50 \%)+150$ ppm ABA & $23.82^{f g}$ & $3.13^{\mathrm{ab}}$ & $375.33^{\mathrm{a}}$ \\
\hline \multirow[t]{2}{*}{$T_{13}$} & Crop load $(75 \%)+400$ ppm ethephon & $22.99^{\text {fon }}$ & $2.90^{\mathrm{bc}}$ & $323.71^{\mathrm{bc}}$ \\
\hline & $\operatorname{LSD}(p \leq 0.05)$ & 2.07 & 0.33 & 28.83 \\
\hline
\end{tabular}

Mean followed by same letter are not significantly differ at $p \leq 0.05$ 
Table 2 : Effect of crop load (bunches per vine) and abscisic acid application on total sugars, uneven colour of berries/bunch and anthocyanin content of Flame Seedless grapes

\begin{tabular}{|c|c|c|c|c|}
\hline S. No. & Treatment & $\begin{array}{l}\text { Total sugars } \\
(\%)\end{array}$ & $\begin{array}{l}\text { Uneven colour of } \\
\text { berries/bunch (\%) }\end{array}$ & $\begin{array}{l}\text { Anthocyanin } \\
\text { (mg per } 100 \mathrm{~g})\end{array}$ \\
\hline$\overline{T_{1}}$ & Crop load (100 \%) - Control & $13.94^{\circ}$ & $45.60^{\mathrm{a}}$ & $24.50^{i}$ \\
\hline $\mathrm{T}_{2}$ & Crop load (75\%) & $14.59^{\mathrm{abc}}$ & $33.20^{\mathrm{bc}}$ & $27.60^{\mathrm{h}}$ \\
\hline $\mathrm{T}_{3}$ & Crop load (50 \%) & $15.00^{\mathrm{abc}}$ & $29.60^{\text {cd }}$ & $31.00^{\mathrm{fg}}$ \\
\hline $\mathrm{T}_{4}$ & Crop load $(100 \%)+50$ ppm ABA & $14.65^{\mathrm{abc}}$ & $35.30^{b}$ & $31.80^{\text {ef }}$ \\
\hline $\mathrm{T}_{5}$ & Crop load $(100 \%)+100$ ppm ABA & $14.38^{\mathrm{bc}}$ & $32.00^{\mathrm{bc}}$ & $34.20^{\text {cde }}$ \\
\hline $\mathrm{T}_{6}$ & Crop load $(100 \%)+150$ ppm ABA & $15.10^{\mathrm{abc}}$ & $34.80^{b}$ & $32.00^{\text {ef }}$ \\
\hline $\mathrm{T}_{7}$ & Crop load $(75 \%)+50$ ppm ABA & $14.90^{\mathrm{abc}}$ & $27.90^{\mathrm{d}}$ & $29.10^{\text {gh }}$ \\
\hline $\mathrm{T}_{8}$ & Crop load $(75 \%)+100$ ppm ABA & $15.92^{a b}$ & $18.70^{\text {ef }}$ & $35.70^{\text {bcd }}$ \\
\hline $\mathrm{T}_{9}$ & Crop load $(75 \%)+150$ ppm ABA & $15.10^{\mathrm{abc}}$ & $16.90^{\text {efg }}$ & $31.80^{\mathrm{ef}}$ \\
\hline $\mathrm{T}_{10}$ & Crop load $(50 \%)+50$ ppm ABA & $15.28^{\mathrm{abc}}$ & $20.00^{\mathrm{e}}$ & $33.40^{\text {def }}$ \\
\hline $\mathrm{T}_{11}$ & Crop load $(50 \%)+100$ ppm ABA & $16.14^{\mathrm{a}}$ & $16.10^{\mathrm{fg}}$ & $38.00^{b}$ \\
\hline $\mathrm{T}_{12}$ & Crop load $(50 \%)+150$ ppm ABA & $15.43^{\mathrm{abc}}$ & $14.60^{9}$ & $41.78^{\mathrm{a}}$ \\
\hline$f_{13}$ & Cropload $(75 \%)+400$ ppm othephe & $14.10^{\circ}$ & $15.40^{\mathrm{fg}}$ & $36.30^{\mathrm{bc}}$ \\
\hline
\end{tabular}

Treatment $\mathrm{T}_{12}$ applied at veraison stage resulted in a higher bunch weight $(375.33 \mathrm{~g})$. In case of untreated vines (100\% crop load), minimum bunch weight $(270.36 \mathrm{~g})$ was recorded. The results suggested that lower crop load and increased concentration of ABA was more effective in bunch weight improvement. The increase in bunch weight, as observed in the present study could be attributed to the effect of cluster thinning (reduced crop load) on increasing the amount of carbohydrates for the growth and development of remaining bunches. These results are in conformity with the findings of Cheema et al., (2003) who reported that greater cluster weight with $50 \%$ cluster thinning along with canopy management was observed in Perlette grapes.

Ripening parameter (Total sugars) significantly improved with combined application of crop load and ABA (Table 2). Application of treatment $T_{11}$ at veraison stage recorded highest mean total sugars (16.14\%), followed by treatment $\mathrm{T}_{8},(15.92 \%)$. Most of the ABA treatments did not differ much from each other but better than untreated vines. On the other hand in control, (100 $\%$ crop load) lowest total sugars (13.94 \%) were recorded. The combined effect of exogenous application of ABA and reduced crop load increased the sugar contents by decreasing acid contents. Similarly, Giribaldi et al. (2011) reported that in grape cv. Cabernet Sauvignon, ABA treatments before véraison, early and mid-véraison stages on berries modified concentration of skin sugar. King et al. (2012) observed that crop removal increased sugar concentration in Hawke's Bay grapes. Somkuwar et al. (2014) observed that concentration of reducing sugar reduced with the increase in number of clusters per vine in grape cv. Jumbo Seedless.
The total soluble solids contents of grape berries found to be significantly improved in fruits of grapevine with low crop load and ABA application as compared to untreated (control) vines retained with full crop load (Fig. 2). Treatment $T_{11}$ (crop load $50 \%+$ 100 ppm ABA) recorded significantly higher TSS (19.15\%), followed by treatments $\mathrm{T}_{8}$ (Crop load $\left.(75 \%)+100 \mathrm{ppm} A B A\right), \mathrm{T}_{12}$ (Crop load $(50 \%)+150$ ppm ABA) and $\mathrm{T}_{13}$ (Crop load (75\%) + 400 ppm ethephon). The minimum TSS (15.22\%) was recorded in $\mathrm{T}_{1}$ (Crop load $100 \%$ - Control). The similar results have been observed earlier in grapes (Sun et al. 2012 and Somkuwar et al. 2014), where the reduction in clusters per vine lead to increase in total soluble solids in grape berries. Likewise, Amiri et al. (2010) observed that application of $A B A$ at veraision stage was more effective than ethephon for enhancing the soluble solids concentrations of fruits in Beidaneh Ghermez grape cultivar. However, in mango ethrel @ 750 ppm was found to be the most suitable for improving physio-chemical traits (Singh et al., 2012).

Significant differences were observed for uneven colour of berries per bunch and anthocyanin content of berries. Uniform berry coloration was promoted by treatment of ABA. The data (Table 2) revealed that significantly lowest uneven berries per bunch $(14.60 \%)$ were recorded in grapevines heated with $50 \% T_{12}$. This was statistically at par with $T_{9}, T_{11}$ and $T_{13}$ treatments in which $16.90,16.10,15.40 \%$ of uneven berries per bunch were recorded, respectively. The highest (45.60\%) uneven berries per bunch were recorded in untreated grapevine with $100 \%$ crop load. The effectiveness of reduced crop load could be attributed to regulation of anthocyanin concentration in berries due to more exposure of bunches to sunlight which leads 


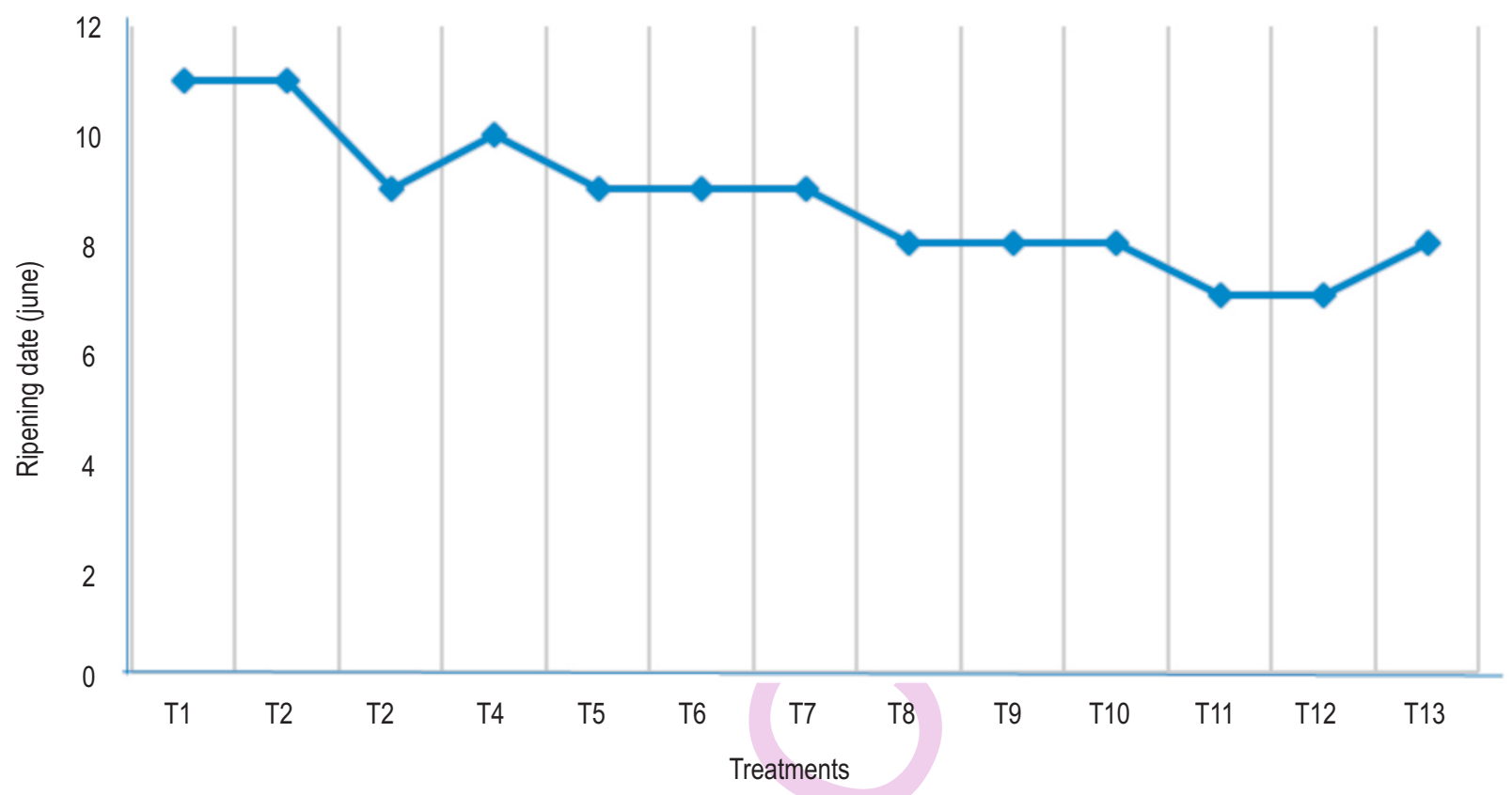

Fig1. Effect of crop load (bunches/vine) and abscisic acid application on time of ripening of Flame Seedless grapes

$$
\operatorname{LSD}(p \leq 0.05)=1.90
$$

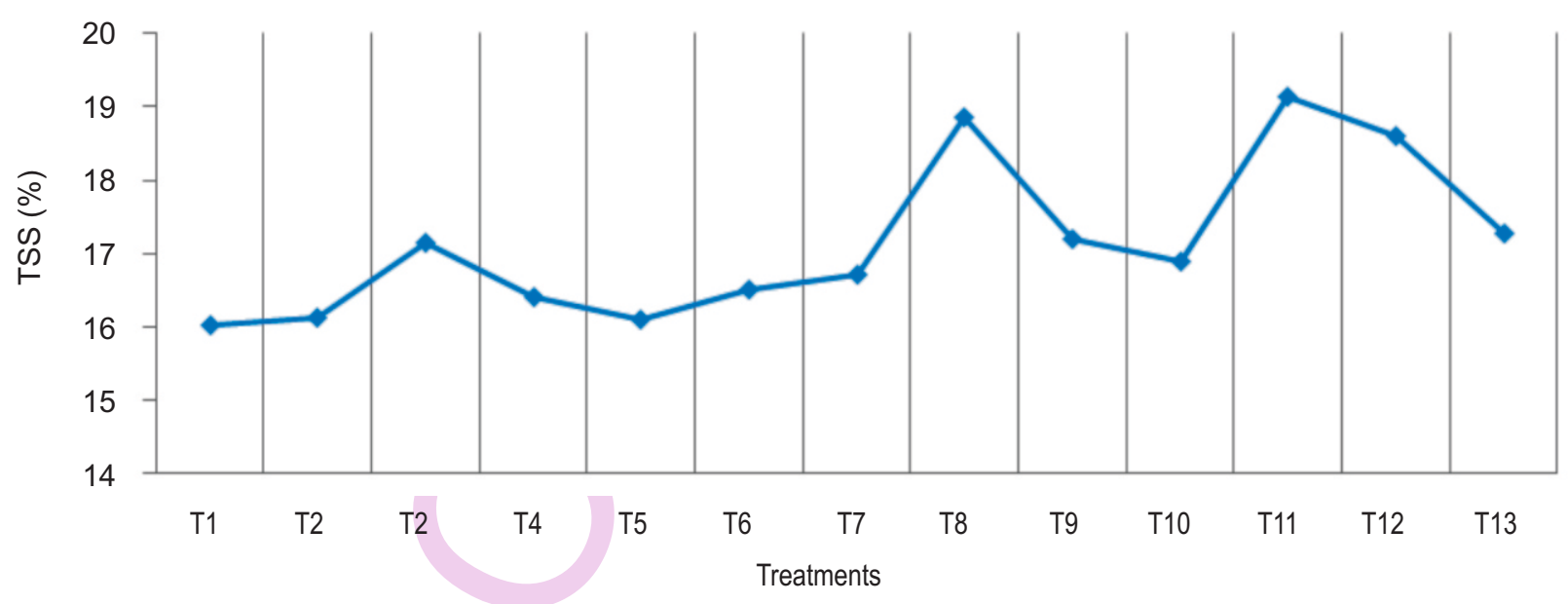

Fig 2. Effect of crop load (bunches/vine) and abscisic acid application on total soluble solids of Flame Seedless grapes

to proper colouration of grapes. Secondly, ABA content is correlated with colour changes in grapes. These results corroborate with the previous findings of Peppi et al. (2006) who reported that application of abscisic acid (ABA) on 'Flame Seedless' grapes led to increased anthocyanin content and fruit colour of berries. Lacampagne et al., (2010) reported a positive impact of ABA on berry colour of grapes. Roberto et al., (2013) found that $A B A$ improved the colour of grapes, especially when applied twice ( 7 days after veraison +15 days before harvest) at $400 \mathrm{mgl}^{-1}$ in 'Rubi' table grapes.

All the treatments resulted in increase in anthocyanin content as compared to control (Table 2). The maximum anthocyanin content was recorded in treatment $\mathrm{T}_{12}$ was noted. However, no significant difference between $\mathrm{T}_{11}$ and $\mathrm{T}_{12}$ treatments. The untreated grapevines (50\%, $75 \%$ and $100 \%$ crop load) 
showed a distinct decrease in anthocyanin content of berries. The treatment in which abscisic acid was sprayed; anthocyanin content ranged from 31.80 to $41.78 \mathrm{mg} 100^{-1} \mathrm{~g}$ was recorded. Thus, results of the present investigations showed that with decrease in crop load and increase in ABA (150 ppm) concentration, anthocyanin content was increased (Table 2). Overall progressive increase in total anthocyanin content was noticed in grapevines which were retained at $50 \%$ crop load treated with ABA at veraison stage. Quiroga et al., (2009) observed higher level of anthocyanin relative to control values with ABA application in field-grown grape cv. Cabernet Sauvignon. Sandhu et al., (2011) observed that exogenous application of ABA enhanced anthocyanin content of muscadine grapes but these effects varied depending upon the cultivar. Koyama et al., (2014) reported that single application of S-ABA $\left(400 \mathrm{mg} \mathrm{l}^{-1}\right)$ at 7 days after veraison was sufficient to increase the anthocyanin concentration of 'Isabel' grapes.

The results of the present study showed that 100 to 150 ppm application of $A B A$ at veraison coupled with $50 \%$ crop load (55-65 clusters per vine) would be helpful in uniform colouration of bunch with improved fruit quality.

\section{References}

Amiri, M.E., E. Fallahi and S. Parseh: Application of ethephon and ABA at $40 \%$ veraison advanced maturity and quality of 'Beidaneh Ghermez' grape. Acta. Hortic., 884, 371-377 (2010).

Anonymous: Indian Horticulture Data Base. National Horticulture Board, Ministry of Agriculture Government of India (2014).

A.O.A.C: "Official Method of Analysis of AOAC International", Vol. II, Suite 500481, North Frederick Avenue, Gaithersburg, Maryland 20877-2417, USA(2005)

Ban, T., M. Ishimaru, S. Kobayashi, S. Shiozaki, N. Goto-Yamamoto and S. Horiuchi: Abscisic acid and 2, 4-dichlorophenoxyacetic acid affect the expression of anthocyanin biosynthetic pathway genes in 'Kyoho' grape berries. J. Hort. Sci. Biotechnol., 78, 586-589 (2003).

Cantin, C. M., M. W. Fidelibus and C. H. Crisosto: Application of abscisic acid (ABA) at veraison advanced red colour development and maintained postharvest quality of 'Crimson Seedless' grapes. Post-harvest Biol. Technol., 46, 237-241(2007).

Cheema, S. S., P. Singh and W.S. Dhillon: Effect of crop regulation and canopy management on fruit quality and disease incidence in grape. Indian. J. Hort., 60, 208-213 (2003).

El-Sayed, M. E. A.: Improving fruit quality and marketing of "Crimson Seedless" grape using some preharvest treatments. J. Hort. Sci. Orna. Plants, 5, 218-226 (2013).

Giribaldi, M., W. Hartung and A. Schubert: The effects of abscisic acid on grape berry ripening are affected by the timing of treatment. J. Int. Sci. Vigne. Vin., 9, 11-29 (2011).

Hiratsuka, S., H. Onodera, Y. Kawai, T. Kubo, H. Itoh and R. Wada: ABA and sugar effects on anthocyanin formation in grape berry cultured in vitro. Sci. Hort., 90, 121-130 (2001).

Kaur, M., M. I. S. Gill and N. K. Arora: Effect of pre-harvest treatments on yield, maturity and quality of Flame Seedless grapes (Vitis venifera L.). J. Hort. Sci., 88, 35-40 (2013).

King, P. D., D. J. Mcclellan and R.E. Smart: Effect of severity of leaf and crop removal on grape and wine composition of merlot vines in Hawke's Bay vineyards. Am. J. Enol. Vitic., 63, $500-507$ (2012).

Koyama, R., A. M. De Assis, L. Y. Yamamoto, W. F. Borges and R.D. Borges: Exogenous abscisic acid increases the anthocyanin concentration of berry and juice from 'Isabel' grapes (Vitis labrusca L.). Hort. Sci., 49, 4460-4464 (2014).

Lacampagne, S., S. Gagne and L. Geny: Involvement of abscisic acid in controlling the pro-anthocyanidin biosynthesis pathway in grape skin: new elements regarding the regulation of tannin composition and leucoanthocyanidin reductase (LAR) and anthocyanidin reductase (ANR) activities and expression. J. Plant Growth Regulation, 29, 81-90 (2010).

Peppi, M. C., M. V. Fidelibus and N. Dokoozlian: Abscisic acid application timing and concentration affect firmness, pigmentation and colour of 'Flame Seedless' grapes. Hort. Sci., 41,1440-1445 (2006).

Quiroga, A. M., F. J. Berli, D. Moreno, J. B. Cavagnaro and R. Bottini: Abscisic acid sprays significantly increase yield per plant in vineyard grown wine grape (Vitis vinifera L.) cv. Cabernet Sauvignon through increased berry set with no negative effects on anthocyanin content and total polyphenol index of both juice and wine. J. Plant Growth Regulation, 28, 28-35 (2009).

Ranganna, S.: Anthocyanin. Handbook of analysis and quality control of fruit and vegetable products. Tata Mcgrow Hill Publishing Co. Ltd., pp. 94-99 (1986).

Roberto, S. R., A. Marinho de Assis, L. Y. Yamamoto, L. C. V. Miotto, R. Koyama, A.J. Sato and R. D. S. Borges: Ethephon use and application timing of abscisic acid for improving colour of 'Rubi' table grape. Pesq. Agropec. Bras., 48, 797-800 (2013).

Sandhu, A. K., J. D. Gray, J. Lu and L. Gu: Effects of exogenous abscisic acid on antioxidant capacities, anthocyanins and flavonol contents of Muscadine grape (Vitis rotundifolia) skins. Food Chemistry, 126, 982-988 (2011).

Setha, S.: Roles of abscisic acid in fruit ripening. Walailak J. Sci. Technol., 9, 297-308 (2012).

Singh, P., M. K. Singh, V. Kumar, M. Kumar and Sunil Malik: Effect of physico-chemical treatments on ripening behavior and postharvest quality of Amarpali mango (Mangifera Indica L.) during storage. J. Environ. Biol., 33, 227-232 (2012).

Somkuwar, R. G., R. R. Samarth, P. Itroutwar and S. Navale: Effect of cluster thinning on bunch yield, berry quality and biochemical changes in local clone of table grape cv. Jumbo Seedless (Nana Purple). Indian J. Hort., 71, 184-189 (2014).

Spayed, S. E., J. M. Tarara, D. L. Mee and J. S. Ferguson: Sepration of sunlight and temperature effects on the composition of Vitis vinifera cv. "Merlot berries". Am. J. Enol. Viticult., 53, 171-182 (2002).

Sun, Q., G. L. Sacks, S. D. Lerch and J. E. V. Heuvel: Impact of shoot and cluster thinning on yield, fruit composition and wine quality of Corot Noir. Am. J. Enol Vitic., 63, 49-56 (2012). 